\title{
AN ANALYSIS OF TEMPORARY IMPORT USING ATA CARNET SYSTEM AT PT.KRAMA YUDHA TIGA BERLIAN MOTORS
}

\author{
Fajrina Rachmawaty ${ }^{1}$, Dinda Pretty Noor ${ }^{2}$, Aswanti Setyawati ${ }^{3}$, \\ Suprihadi ${ }^{4}$ \\ 1. STMT Trisakti, 2. STMT Trisakti, 3. STMT Trisakti, 4. STMT Trisakti \\ $\bowtie$ corresponding author: fajrinarachmawaty@gmail.com
}

\begin{abstract}
The purpose of this research is to describe the advantages of using ATA Carnet system for temporary import activities in order to the company corporate and business especially in Indonesia can implement this system in the process of the activity temporary imports and also to know the comparison on the import process while using ATA Carnet than with regular system for temporary import. This can be seen with to efisiensian of the ATA Carnet system for temporary import process compared to the system temporary imports. This research methodology uses qualitative descriptive with primer and secondary data this data acquired in more or less in term 1 last year from 2016 until 2017. The research is limited to PT Krama Yudha Tiga Berlian Motors in Department of import export. Then you can conclude and in the know that the use of the ATA Carnet system for temporary import activities in the process can minimize the time estimation procedures and faster when compared with the usual process of temporary import activities. Thus the ATA Carnet system is a winning system and can make it easier to also streamline the activities of the temporary import process and expected there would be further research in the company other companies that carry out temporary import.
\end{abstract}

Keywords : ATA,Carnet,System,Temporary,Import

\section{Introduction}

The role of logistics is essential and an integral part of the activities of an enterprise, both in the field of logistics or not related to logistics. for example, the company distributes its products to customers using logistics distribution network.(Edi, n.d.)

Logistics management is one of the activity focuses on how to manage the goods through action, planning and determination of requirements, procurement, storage, distribution, maintenance and removal to achieve a goal that has been on set.(Sitorus, Jenderal, \& Perhubungan, 2017)

In a country's economic activity there is an activity or process of shipping goods from country to country with import and export. One of the activities from the delivery of the goods is the process of import. 
Import is an activity place of goods or commodities from one country to another within the country,temporary import is an activity place of goods or other commodities into the customs area with the a certain time. The process of import or export we know certainly has a wide range of procedures to the destination in the State are safe and secure. The process of delivery of the goods require scheme/Groove, the ATA Carnet system prior to the import process while the import procedure is executed while always. On the import procedure while this takes quite a long time several stages, thus deriving a system or procedure imports while a new more efficient in time and procedure the ATA Carnet System.

The ATA Carnet is a document and a system for import/export activities while can be used in coverage area of 75 countries. Carnet is an international Customs document accepted as Customs Notices and includes guarantees that apply internationally. Simply put the ATA Carnet is termed as a "Passport for goods". The application of the ATA Carnet is intended to simplify and expedite the procedure for temporary import and export in an effort to facilitate the international business world. The application of the ATA Carnet is made after Indonesia ratified the Convention on Temporary Admission/entry permit (Convention on Temporary Admission), Istanbul 1990.

Import is an item of income into the customs area. the transaction import is a trade by way of the inclusion of goods from a foreign country into the customs area of Indonesia with laws comply with the provisions of applicable invitation (Tandjung, 2011:379)

In order to minimize the cost and improve the effectiveness and eficiency of export-import, many companies (exporters) consider that using freight forwarding service is a right solution. That many companies have such an opinion is an opportunity, making many freight forwarders emerges.(Ricardianto, n.d.)

Multimoda transportation is the main component that play an important role in supporting the chain of logistics systems(S, n.d.)

Import can be defined as the activities incorporate items from a country (Foreign Affairs) to the customs territory of the other country. This sense has the sense that import activities involving the two countries means, in this case 
can be represented by the interests of the two companies between the two countries. (Susilo,2008:10).

Logistic management is a scientiic knowledge about planning and determining needs, procurement, storage, distribution, and maintenance as well as writing off material/equipment.(Raden Didiet Rachmat Simarmata \& Len Togas, 2015)

This it can be concluded that imports, namely international trade activities by way of embodying the goods to customs territory of indonesia conducted by individuals or companies engaged in the import export with comply with the provisions of the regulation militate in the applicable invitation which is subject to import duty.

A. Temporary Import is the infusion of imported goods into the customs area are really meant for export in return for a period of not longer than 3 years. Import while set in the regulation of the Minister of finance Number 142/FMD. 04/2011 general regulations and customs and Excise Number PER-51/BC/2012.

B. Carnet is a document international customs over imported goods while with the international guarantee system through the guarantee over the import duties and taxes.

\section{Type Of Carnet System}

\section{CPD Carnet}

CPD Carnet used for motor vehicle or means of transport, valid for 12 months and can be extended with 1 time period-given the same as before.

\section{ATA Carnet}

ATA Carnet is used for the purposes of pecans Kingdom, exhibitions, performances,similar activities, professional equipment, and expert on education, sports, tourist and humanitarian purposes. Valid for 12 months.

C. In Indonesia began has now been established that imported goods while mandatory pocketed ATA/CPD Carnet passport. Directorate General of Customs issued a new procedure to bring branag from overseas which is only stopped temporarily in within the country. The procedure in the form of system ATA/CPD Carnet documentation import export temporary 
passport as befits a national customs documents.

Multilateral International Customs Cooperation Kasubdit DJBC Imik Eko Putro explains the application of the ATA/CPD Carnet aims to facilitate the community in bringing in goods from abroad for exhibitions, concerts, sporting events internasinal standards and other international activities. ATA Carnet serves as the temporary import and export documents that are intended to be imported back within a certain period. This stuff is already valid passport plural in 84 countries and accounting for 17 February bsejak January 2015 already imposed in Indonesia.

According to Imik, goods that are recorded in the category of ATA/CPD then no longer need to do logging. Exporters and importer no longer need to pay customs tax guarantees. (CNN Indonesia)

D. About the ATA Carnet System

The ATA Carnet is a system that was agreed upon after a tackle in the ATA Convention in Istanbul on July 30, 1963, and authorized by the International Chamber of Commerce, in the form of temporary licensing agreement or the passport for the displacement of a number of items without requires a letter of guarantee, tax or customs formalities. The ATA Carnet is one of the trading facilities currently used by the majority of countries in the world to facilitate the traffic of goods and/or services between countries.

Currently, the ATA and CPD carnet has been used in more than 70 countries in the world, such as America, Canada, South Africa, Australia, China, Taiwan, Hong Kong, India, Japan, Korea, Malaysia, Singapore, Thailand and others.

Indonesia officially joined the international guarantee chain Carnet ATA on 1 October 2014 due to the ratification of the Convention, the Government accepted annex on documents while income in the form of exhibits, professional equipment, goods with the purpose of education/science/cultural products, personal items, goods/tourist needs of humanity, and means of transportation. In Indonesia this system came into force since 17 February 2015. For businessmen, the ATA Carnet provides ease in administration, less written document, less legal 
conflicts, less time and cost of customs, licensing and reduce the risk. For the Government, it will improve the productivity, and the existence of the guarantee of payment of all taxes and customs duty. With an ATA Carnet, the procedures for releasing import duties and taxes become simple, the process of importing and importing goods while not complex, is guaranteed by the international guarantee chain. Criteria for items that can use an ATA Carnet procedure is limited to goods with the purpose of performances or exhibitions, professional tools, education, personal use of travelers and sports, and humanity. The CPD carnet may be used for commercial purposes and the means of transport of the imported or exported private goods within a certain period. The nature of goods that can use the ATA Carnet system is that they are not easily discharged, easily identified and do not change the form unless such goods are experiencing shrinkage.

E. Legal basis Carnet in Indonesia

1. REGULATION NO. $89 / 2014$

2. PERMENKEU No. 228/FMD. 04/2014

3. PERMENKEU No. 553/km. 4/2015

4. Regulation of FMD 228 Regulation of the Minister of Finance of Republic Indonesia No. 228/FMD. 04/2014

About: The temporary import or export of goods using the Carnet which are intended to be imported back in a specific time period by using the carnet

Decided: Regulation of the Minister of Finance of import about the use of carnet for exported goods to be imported again within a specific time period.

\section{Method}

This research uses qualitative descriptive methods by using primer data from observation interview with Mr. Edi Cahya as ATA Carnet Handler at Customs and Employee Import Export Departement from PT. KRAMA Yudha Tiga Berlian Motors over a period of three months calculated from the date 1 August 2016 until 1 November 2017. It also uses the data in term 1 of 2016-2017 in the import export department. 
The research is qualitative in nature. A qualitative research is defined as an inquiey process of understanding a social or human problem social or human problems, based on building a complex, holistic picture, well- formed with words, reporting detailed views of informants, and conducted in a setting of naturan . (Creswell,1994)

Instrumental Input of this research is PMK NO.228

Input of this research is the condition of temporary import.

Subject of this research is Customs, importer and consignee.

Object of this research is Indonesian Logistic and Import System.

Output of this research is the realization of temporary import activity while becoming efficient and effective.

Table 1. Temporary import using a regular

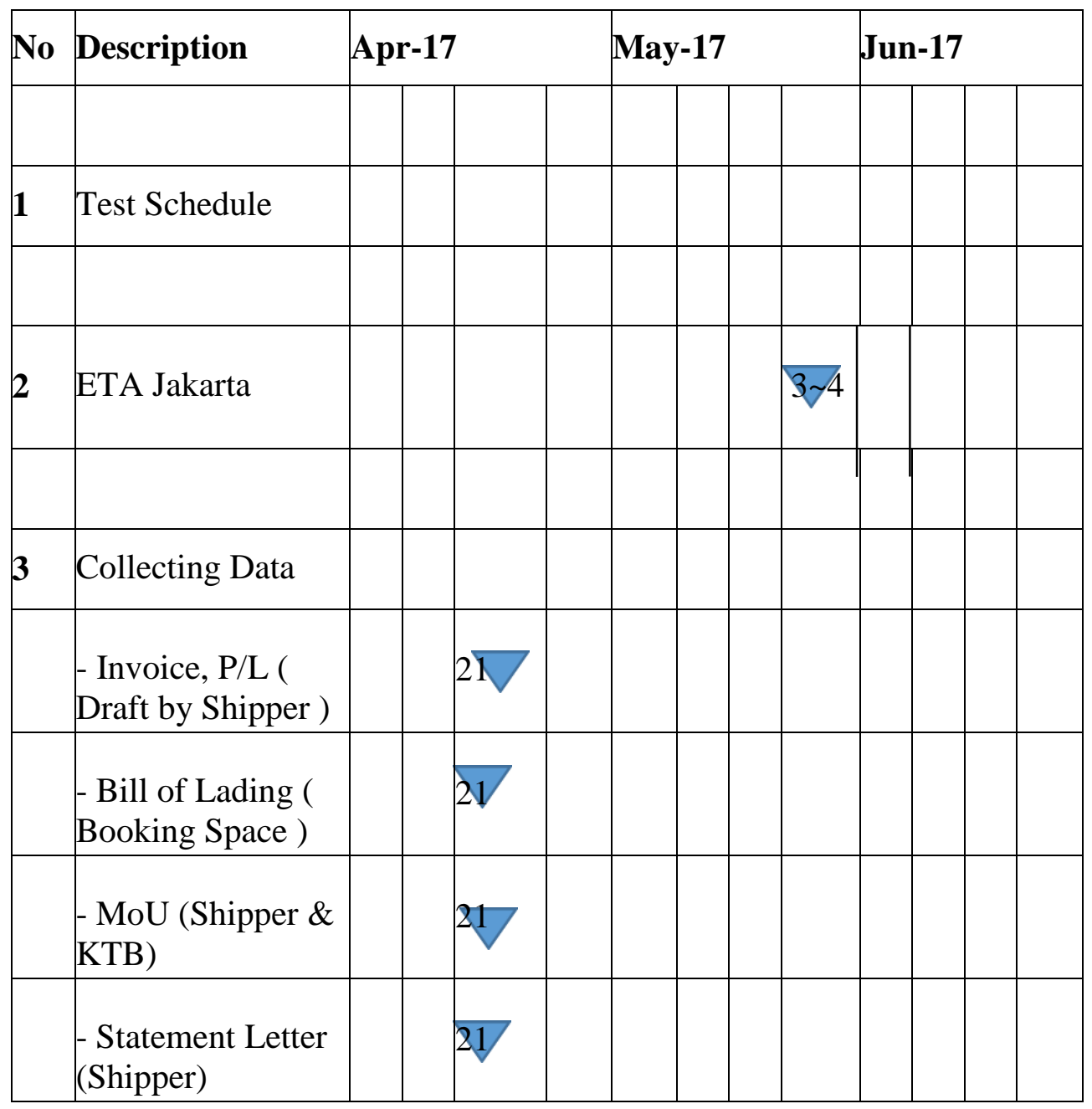


Table 1, Cont. Temporary import using a regular

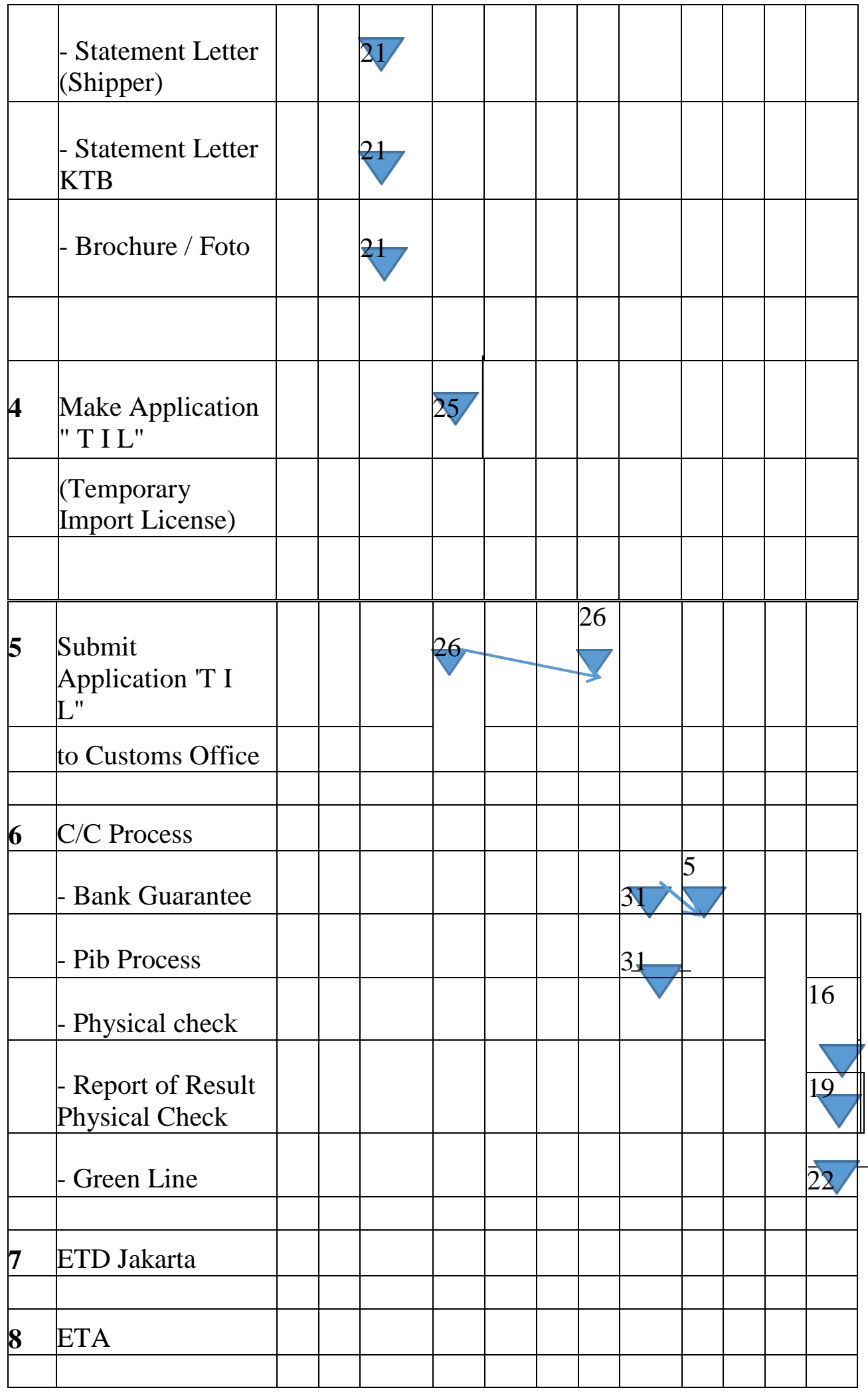




\section{Discussion and Result}

Temporary Import License Scheme with Regulary System

The following documents must be prepared before applying temporary imports:

1. Value of goods such as invoice, packing list and shipping document (b/l or AWB)

2. The certificate regarding the number and type of goods (description of goods) such as brochures, catalogues, photographs of the goods

3. Leasing Agreement/lease/purchase order between the supplier with the recipient of goods

4. The affidavit (statement letter) from the Origins/Shippers that the goods used in the KTB as what and for what

5. Affidavit of KTB that such goods will be re-exported, in use for what, how long and where

Explanation:

The activities of the temporary import without using the ATA Carnet system simply takes a long time compared to using the ATA Carnet System. The activities conducted by using ATA Carnet system will only take one month period, whereas those not using the ATA Carnet System need approximately 3 months.

Table 2. Scheme Of Importation With Ata Carnet

\begin{tabular}{|c|c|c|c|c|c|c|c|c|c|c|c|c|c|c|c|c|}
\hline \multirow{2}{*}{ No } & \multirow{2}{*}{ Description } & \multicolumn{15}{|c|}{ Time Estimate } \\
\hline & & \begin{tabular}{l|l}
1 & 5 \\
\end{tabular} & \begin{tabular}{l|l}
5 & 10
\end{tabular} & & & 15 & 16 & 17 & 18 & 19 & 22 & 23 & 24 & 25 & 26 & 29 \\
\hline 1 & $\begin{array}{l}\text { Submission of } \\
\text { ATA CARNET By } \\
\text { Shipper }\end{array}$ & & & & & & & & & & & & & & & \\
\hline 2 & Exhibition Period & & & & & & & & & & & & & & & \\
\hline 3 & ETD Japan & & & & & & & & & & & & & & & \\
\hline 4 & ETA Jakarta & & & & & & & & & & & & & & & \\
\hline 5 & $\begin{array}{l}\text { Receive Document } \\
\text { from Shipper }\end{array}$ & & & & & & & & & & & & & & & \\
\hline & $\begin{array}{l}\text { - Copy ATA } \\
\text { CARNET CARD ( } \\
\text { Shipper ) }\end{array}$ & & & & & & & & & & & & & & & \\
\hline & $\begin{array}{l}\text { - Copy Packing } \\
\text { List, Bill of Lading } \\
\text { ( Shipper ) }\end{array}$ & & & & & & & & & & & & & & & \\
\hline 6 & $\begin{array}{l}\text { Receive Document } \\
\text { from Shipper }\end{array}$ & & & & & & & & & & & & & & & \\
\hline
\end{tabular}


Table 2, Cont. Scheme Of Importation With Ata Carnet

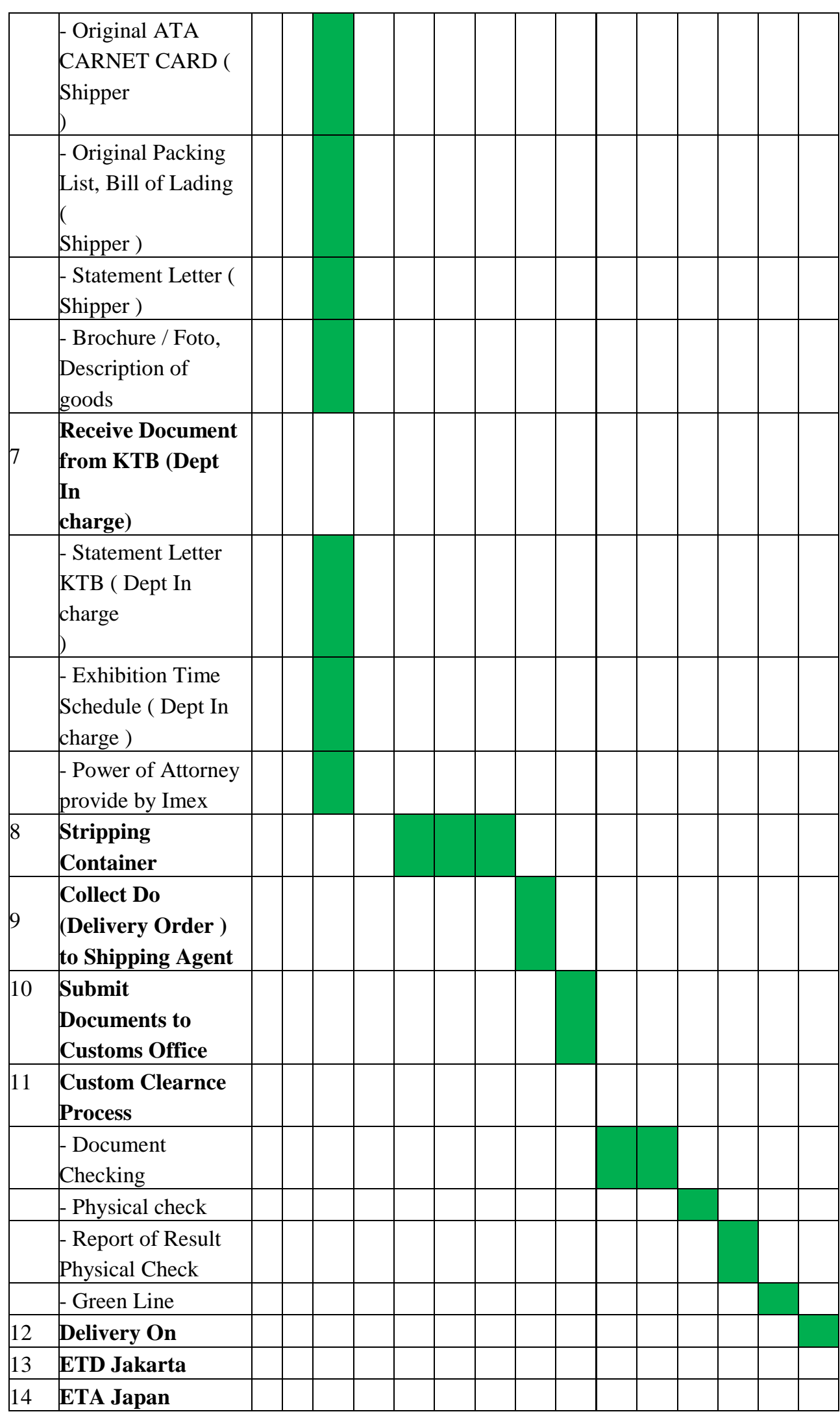


The documents should be prepared before applying for temporary import with ATA CARNET as follows :

1. Original ATA CARNET Card

2. Bill of Lading (B / L), Packing List First

3. Description of goods : Quantity, type of good, brochures, catalogs, photo, etc

4. Statement letter by shipper that the items are used in KTB

5. Statement letter of KTB that the goods will be Re-Import,Purpose of utility, time schedule and Place

: Goods

Explanation:

Goods sent from Japan on the 1st, 5th and 6th at the date of the receipt of the document from the sender (COPY of ATA CARNET CARD, COPY of the PACKING LIST, BILL OF LADING) on 10th acceptance of original documents from the sender (the ORIGINAL ATA CARNET CARD, ORIGINAL BILL OF LADING, STATEMENT LETTER MOTORCYCLE PHOTOS, BROCHURES OR DESCRIPTIONS OF GOODS). On the 10th received a document from PT. KRAMA Yudha Tiga Berlian form Statement letter KTB, Exhibition time schedule, power of attorney provide by Imex (power of attorney). On 13 items arrived in Jakarta, on 15 to 17 the process of shipping container, dated 18 Collect DO (Delivery Order to the sender's agent). The 19th place all documents to the Customs Office, on 22 to 23 in the process of customs clearance documents, checking the 24th do checking of the condition of the goods, the 25th report done over the checking of the goods, the date of 26 items sign in to the green line, on the 29th of goods already delivered to PT. Krama Yudha Tiga Berlian. No Description of Goods Import Document Preparation Green Line

1 Concept Car (Truck) 07 July 201729 July 2017

2 Concept Car (Passenger Car) 20 July 201709 August 2017

3 Accessories for Concept Car 23 July 201709 August 2017

Using the ATA Carnet system for temporary import process only takes an 
item for 1 month.

The following is a history of data import process comparison while ATA Carnet and Regular

Table 3. With ATA Carnet System

\begin{tabular}{|r|l|r|r|}
\hline No & \multicolumn{1}{|c|}{$\begin{array}{c}\text { Description of } \\
\text { Goods }\end{array}$} & $\begin{array}{c}\text { Preparation } \\
\text { Import } \\
\text { Document }\end{array}$ & $\begin{array}{c}\text { Green } \\
\text { Line }\end{array}$ \\
\hline 1 & $\begin{array}{l}\text { Concept Car } \\
\text { (Truck) }\end{array}$ & 07 July 2017 & $\begin{array}{r}\text { 29 July } \\
2017\end{array}$ \\
\hline & Concept Car & 09 \\
2 & (Passenger Car) & 20 July 2017 & $\begin{array}{r}\text { August } \\
2017\end{array}$ \\
\hline \multirow{2}{*}{3} & Accessories for & 23 July 2017 & August \\
Concept Car & 2017 \\
\hline
\end{tabular}

Table 4. With Regular System

\begin{tabular}{|c|l|r|r|}
\hline No & $\begin{array}{l}\text { Description of } \\
\text { Goods }\end{array}$ & $\begin{array}{c}\text { Preparation } \\
\text { Import } \\
\text { Document }\end{array}$ & \multicolumn{1}{c|}{$\begin{array}{c}\text { Green } \\
\text { Line }\end{array}$} \\
\hline \multirow{2}{*}{1} & $\begin{array}{l}\text { Measurement } \\
\text { Equipment and }\end{array}$ & 18 & 01 \\
& Auto & November & February \\
2015 & 2016 \\
\hline
\end{tabular}

\section{Conclusion}

From the results of this research it can be concluded that the import process will become more efficient and effective using ATA Carnet system. It is due to the fact that the ATA Carnet system really helps speed up the process of import of the goods, lessen the procedures, and minimize the time required. The results of this research can also serve as consideration for the PT. KRAMA Yudha Tiga Berlian Motors to use ATA Carnet system for temporary import activities and for other business to be interested in using it. It can also serve as additional knowledge about the temporary import activities and as a reference for other researchers who will examine the temporary import.

\section{References}

Creswell,J.W.1994, Research Design: Qualitative And Quantitative Approaches. Nebraska: Sage Publications Inc. (1994), 1994. CNN Indonesia,DJBC.2015. Kemenkeu-March 11.2015 Susilo Andi,2008, Buku Pintar Ekspor Impor. Jakarta: Transmedia Marolo 
Tanjung.2011, Aspek Dan Prosedur Ekspor Impor.Jakarta : Salemba Empat

Sugianto,2008. Pengantar Kepabeanan Dan Cukai. Jakarta: Cikal Sakti CNN Indonesia,2015. Barang Impor Sementara Wajib Kantongi Paspor. Jakarta.

Purwito, M.Ali 2010, Kepabeanan Dan Cukai Konsep Dan Aplikasi. Jakarta: Pusat Kajian Fiskal FHUI

Peraturan Menteri Keuangan Republik Indonesia Nomor 228/PMK.04 (2014). Impor Sementara Dengan Menggunakan Carnet.

Edi, D. W. (N.D.). Biaya Logistik Dan Kelancaran Pengiriman Logistic Costs And The Good' S Delivery, 3(2), 227-243.

Raden Didiet Rachmat Simarmata, J. H., \& Len Togas, N. (2015). Study On The Cause Of Stock Out Of Logistic Installation In Harapan Kita Hospital. Jurnal Manajemen Transportasi \& Logistik, 2(1), 79-92.

Ricardianto, P. (N.D.). Handling Standard Operating Procedure Export Document Ocean Freight, 2(1).

S, T. I. H. (N.D.). Multimoda Dalam Mewujudkan Visi Logistik Indonesia 2025, 69-84.

Sitorus, B., Jenderal, S., \& Perhubungan, K. (2017). Dukungan Transportasi Logistik Dan Daya Saing Indonesia Dalam Menghadapi The Support Of Logistics Transportation And Indonesian Competitiveness In Dealing, 4(2), 137-146. 